\title{
Status of the genus Wrixonia F.Muell. (Lamiaceae)
}

\author{
T.C. Wilson ${ }^{1,2}$, M.J. Henwood ${ }^{2}$ and B.J. Conn ${ }^{1,2}$ \\ ${ }^{1}$ National Herbarium of New South Wales, Mrs Macquaries Road, Sydney NSW 2000, Australia \\ ${ }^{2}$ School of Biological Sciences, University of Sydney, NSW 2006, Australia \\ Author for correspondence: trevor.wilson@sydney.edu.au
}

\begin{abstract}
Wrixonia F.Muell is here reduced to the synonymy of Prostanthera Labill., and the new combination P. prostantheroides (F.Muell.) T.C.Wilson, M.J.Henwood \& B.J.Conn is made. The other species previously placed in Wrixonia reverts to its earlier name, P. schultzii F.Muell. ex Tate. A modified key to genera of the tribe Westringieae is provided.
\end{abstract}

\section{Introduction}

Wrixonia F.Muell. is one of six genera within the Australian endemic tribe Westringeae Bartl. (subfamily Prostantheroideae, Lamiaceae) (Conn 2004). The genus has clear morphological affinity with Prostanthera, the largest genus of the tribe. Wrixonia flowers are similar to the white or variously mauve-purple flowers of Prostanthera section Prostanthera (Conn 1984); with calyx lobes unequal and abaxial lobe infolding over the developing mericarps; and corolla broad, white, with a longer abaxial median lobe relative to the adaxial median lobe-pair (Carrick 1976; Conn 2004). In contrast, the flowers of Prostanthera section Klanderia have equal or subequal bilobed calyces that remain open as the mericarps mature; and the corolla is narrow, variously red, yellow or green, never white or mauve-purple, with adaxial median lobe-pair longer than abaxial median lobe (Conn 1984). When Mueller (1876) described the genus Wrixonia he expressed some doubt about the taxonomic position of his new species, $W$. prostantheroides F.Muell., by proposing the manuscript name 'Prostanthera wrixoni' if this taxon were to be included in Prostanthera ("Planta, si intra Prostantheram inclusa, P. Wrixoni dicenda" - (Mueller 1876, p. 18). However, Carrick (1976) maintained von Mueller's generic concept and transferred Prostanthera schultzii F.Muell. ex Tate to the genus, as Wrixonia schultzii (F.Muell. ex Tate) Carrick. He asserted that Wrixonia could be unequivocally distinguished from Prostanthera by the flowers of the former having two fertile abaxial anthers that lack anther appendages and two sterile adaxial stamens (hence staminodes), whereas Prostanthera has four fertile anthers that frequently have appendages.

Morphological phylogenetic analyses indicated that Wrixonia and Prostanthera (including Eichlerago) are sister taxa (Abu-Asab and Cantino 1993; Cantino 1992; Conn 1992). Cantino (1992) also demonstrated that Wrixonia is more closely related to Prostanthera section Prostanthera than to section Klanderia by one synapomorphy: the closed fruiting calyx. Results from a molecular phylogenetic study (Wilson 2010) using nuclear (ETS) and plastid (trnT-F) DNA found that Prostanthera is paraphyletic with respect to Wrixonia. Thus, in order to maintain a monophyletic Prostanthera, Wrixonia is here reduced to the synonymy of Prostanthera. 


\section{Key to genera of Westringieae}

The modified key to genera, provided here, reflects the generic concepts proposed by Conn (2004), but accomodates the inclusion of Wrixonia within Prostanthera. Although molecular and morphological phylogenetic analyses demonstrate that Hemigenia and Microcorys are both polyphyletic (Guerin 2008), insufficient data are available to evaluate the full implications on the taxonomy of these genera. Guerin (2008) recommended further analysis using additional molecular markers and taxa.

1. Calyx 2-lobed; stamens with anthers 2-loculate; leaves and branchlets frequently aromatic when crushed Prostanthera

1: Calyx 5-lobed; stamens with anthers 1-loculate; leaves and branchlets non-aromatic .......................... 2

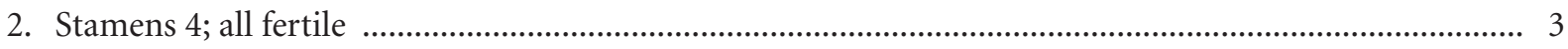

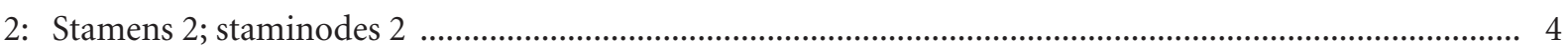

3. Anther with connective terminating in a minute lobe, not readily visible .............................. Hemiandra

3: Anther with connective elongated and distinct; abaxial stamens terminating in a short, dilated, crested end; adaxial stamens attenuated and glabrous, or with an imperfect locule at the end Hemigenia

4. Connective of fertile stamens elongated, extending beyond insertion of staminal filament into a short, dilated and bearded end Microcorys

4: Connective of fertile stamens not or only minutely extended beyond the insertion of staminal filament Westringia

The description of Prostanthera, as provided by Conn (2004), is here modified to accommodate the presence of staminodes as found in the two species previously included in Wrixonia.

Prostanthera Labill. Novae Hollandiae Plantarum Specimen 2: 18, t. 157 (1806). Type species: Prostanthera lasianthos Labill.

Synonym: Wrixonia F.Muell. Fragmenta Phytographiae Australiae 10: 18 (1877). Type species: Wrixonia prostantheroides F.Muell.

For full generic taxonomy refer to Conn (1984).

Shrubs or subshrubs, rarely trees; branches and leaves usually \pm strongly aromatic when crushed; branches mostly \pm round in cross section (except distal branchlets usually quadrangular in cross-section). Leaves decussate, rarely ternate. Inflorescence terminal, thyrsoidal, with flowers either on leafy branches (hence appearing axillary) and uniflorescences (part inflorescences) usually few-flowered or inflorescence leafy to bracteate, botryoidal or paniculate; pherophylls soon caducous; prophylls 2. Calyx 2-lobed, with lobes unequal, enclosing developing fruit (section Prostanthera) or remaining open. Corolla white, pale mauve, olivaceous, red, often pinkish, mid (metallic) blue-green, occasionally yellow; tube expanded in throat; 5-lobed (corolla usually appearing 2-lipped); abaxial median lobe initially extended forward to usually spreading; lateral lobes extended forward, spreading to variously recurved; adaxial median lobe-pair erect to extended forward. Stamens 4 , all fertile or adaxial pair reduced to \pm club-shaped staminodes; fertile anthers 2-loculate, with connective often elongated into a basal appendage. Fruit of 4 mericarps enclosed by calyx tube and lobes, abaxial calyx lobe infolded over developing mericarps (section Prostanthera) or lobes remaining open (section Klanderia). About 100 species, all endemic to Australia.

Prostanthera prostantheroides (F.Muell.) T.C.Wilson, M.J.Henwood \& B.J.Conn, comb. nov.

Basionym: Wrixonia prostantheroides F.Muell. Fragmenta Phytographiae Australiae 10: 18 (1876).

Lectotype (here chosen): J. Young s.n., 27 Oct. 1875, 'In vicinia montis Churchmani', Western Australia (MEL502314); isolecto.: MEL502315.

The type material of this species consists of almost leafless branches. The lectotype (MEL502314) consists of four branches with fragments of flowers and vegetative material in packet labeled 'Wrixonia prostantheroides' 'near Mt. Churchman' [in unknown hand]. The isolectotype (MEL502315) consists of three branches with fragments in packet labeled 'Wrixonia prostantheroides' [same handwriting as for MEL502314]; left specimen with old calyces, right specimen with an old flower. 
Prostanthera schultzii F.Muell. ex Tate, Botany of the Horn Expedition 173 (1896). Synonym: Wrixonia schultzii (F.Muell. ex Tate) Carrick, Journal of the Adelaide Botanic Garden 1: 28-30 (1976).

Lectotype (designated by Carrick 1976): R. Tate s.n., Jun 1894, 'summit of Mount Sonder', Northern Territory (MEL43620).

\section{Acknowledgments}

The Joyce Vickery Scientific Research Grant (Linnaean Society of New South Wales) generously supported the research of one of us (TCW). Herbarium specimens held at CANB, MEL and NSW were examined. We thank Directors and staff of all organisations for making these collections available to us.

\section{References}

Abu-Asab MS, Cantino PD (1993) Systematics Implications of Pollen Morphology in Tribe Prostanthereae (Labiatae). Systematic Botany 18: 563-574.

Cantino PD (1992) Evidence for a polyphyletic origin of the Labiatae. Annals of the Missouri Botanical Garden 79: $361-379$

Carrick J (1976) Studies in Australian Lamiaceae 1. The genus Wrixonia (Prostantheroideae). Journal of the Adelaide Botanic Gardens 1: 27-34.

Conn BJ (1984) A taxonomic revision of Prostanthera Labill. section Klanderia (F.v. Muell.) Benth. (Labiatae). Journal of the Adelaide Botanic Gardens 6: 207-348.

Conn BJ (1992) Relationships within the tribe Prostanthereae (Labiatae). Pp. 55-64 in Harley RM and Reynolds T (eds) Advances in Labiate Science. (Royal Botanic Gardens: Kew)

Conn BJ (2004) IV. Subfam. Prostantheroideae. Pp. 167-275 in Kadereit JW (ed.) Flowering Plants-Dicotyledons, Lamiales (except Acanthaceae including Avicenniaceae), vol. 7. (Springer-Verlag: Berlin)

Guerin GR (2008) Evidence for polyphyly in Hemigenia and Microcorys (Lamiaceae: Westringieae). Australian Systematic Botany 21: 313-325.

Mueller FJH von (1876) Fragmenta Phytographiae Australiae 10: 18.

Wilson TC (2010) The Evolution of Pollination in Prostanthera (Labill.). Unpublished Ph.D. Thesis, 189 pp. (University of Sydney: Sydney) 
